\title{
PHYSIOLOGICAL EVALUATION OF HEAT STRESS IN GESTATING SOWS UNDER DIFFERENT HOUSING SYSTEMS IN BEDDING AND CONCRETE FLOOR
}

\author{
MARIA L. A. NUNES ${ }^{1}$, KÉSIA O. DA S. MIRANDA ${ }^{2}$, JOÃO M. B. A. DE FARIA ${ }^{3}$, \\ AFRÂNIO M. C. VIEIRA ${ }^{4}$, IRINEU ARCARO JÚNIOR ${ }^{5}$
}

\begin{abstract}
The purpose of this paper was to observe the use of bedding (wood shavings) in physiological variables that indicate thermal stress in gestating sows. The experiment was conducted in order to evaluate the effect of two types of floor (concrete and wood shavings). Worse microclimatic conditions were observed in bedding systems $(\mathrm{P}<0.05)$, with an increase in temperature and enthalpy of $1.14{ }^{\circ} \mathrm{C}$ and $2.37 \mathrm{~kJ} . \mathrm{kg}$ dry air ${ }^{-1}$, respectively. The floor temperature at the dirty area was higher in the bedding presence in comparison to its absence. In spite of the worse microclimatic conditions in the bedding, the rectal temperature did not differ significantly $(\mathrm{P}>0.05)$ but the skin surface temperature was higher in the bedding systems. The same occurred with the respiratory rates. The physical characteristics of the floor material influenced the rate of heat loss by conductance. Estimated values were 35.04 and $7.99 \mathrm{~W} \mathrm{~m}^{-2}$ for the conductive heat loss between the animal and floor for treatments with or without bedding, respectively. The use of bedding in sow rearing has a negative impact on microclimatic conditions, what implies in thermoregulatory damages.
\end{abstract}

KEYWORDS: Swine, thermal regulation, zootechnical installations.

\section{AVALIAÇÃO FISIOLÓGICA DE ESTRESSE POR CALOR EM PORCAS GESTANTES SUBMETIDAS A DIFERENTES SISTEMAS DE ALOJAMENTO EM CAMA E EM PISO DE CONCRETO}

RESUMO: Objetivou-se verificar o efeito do uso de cama de maravalha em aspectos bioclimáticos da criação de porcas gestantes. O experimento foi conduzido de forma a avaliar o efeito de dois tipos de piso (concreto e cama de maravalha). Piores condições climáticas foram observadas nos sistemas em cama de maravalha $(\mathrm{P}<0.05)$, com aumento da temperatura e da entalpia específica do ar em $1.14^{\circ} \mathrm{C}$ e $2.37 \mathrm{~kJ} . \mathrm{kg}$ ar seco ${ }^{-1}$, respectivamente. A temperatura do piso na área suja foi maior na cama, em relação ao sistema sem cama. Apesar das piores condições microclimáticas em cama, a temperatura retal não diferiu significativamente $(\mathrm{P}>0.05)$, mas as temperaturas superficiais da pele foram maiores no sistema contendo cama. O mesmo ocorreu com a frequência respiratória. As características físicas dos materiais de piso influenciaram sobre a taxa de perda de calor por condução. Foram estimados valores de 35.04 e 7.99 W.m ${ }^{-2}$ para a perda de calor condutivo entre animal e piso para os tratamentos sem e com cama, respectivamente. A utilização de cama na criação de matrizes suínas impacta negativamente nas condições do microclima, o que reflete em prejuízos termorregulatórios evidenciados pelas variáveis fisiológicas avaliadas.

PALAVRAS-CHAVE: suínos, termorregulação, instalações zootécnicas.

\footnotetext{
${ }^{1}$ Professora. Departamento de Zootecnia, Universidade do Estado de Santa Catarina, Chapecó - SC, e-mail: maria.anunes@udesc.br

${ }^{2}$ Professora, Escola Superior de Agricultura "Luiz de Queiroz", Universidade de São Paulo -Piracicaba - SP.

${ }^{3}$ Bacharel em Estatística - Universidade de Brasília.

${ }^{4}$ Professor. Departamento de Estatística - Universidade Federal de São Carlos.

${ }^{5}$ Pesquisador, Instituto de Zootecnia, Nova Odessa - SP.

Recebido pelo Conselho Editorial em: 27-6-2012
}

Aprovado pelo Conselho Editorial em: 18-8-2013 


\section{INTRODUCTION}

The environment has a direct impact on the productive efficiency of herbs and animal thermal welfare. In swine production, different animal categories have specific thermal comfort ranges. For gestating sows, this range falls between 7 and $23^{\circ} \mathrm{C}$ (NOBLET et al., 1989).

Studies on alternative housing systems for gestating sows are important in order to follow the requirements for the elimination of crates. In this sense, SILVA et al. (2008) verified that the housing of group-penned gestating sows resulted in minor incidence of behaviors concerned environmental stresses when compared to the use of crates. Different aspects of group pens must then be evaluated, such as thermal comfort.

Bedding use for swine production has been seen as an interesting productive alternative when environmental issues are considered (CORRÊA et al., 2009). Furthermore, the use of bedding is related to the animal welfare (HOTZEL et al., 2009; AVERÓS et al., 2010). Despite these positive aspects, bedding use in swine production also presents disadvantages to what concerns thermal comfort (CORDEIRO et al., 2007).

CORRÊA et al. (2009) verified that the use of a bedding thinner layer improves thermal comfort conditions of grow-finishing swines. However, there are few studies on the evaluation of bedding use in the housing of gestating sows regarding the impacts on their thermal comfort.

Physiological measures, such as skin surface temperature, rectal temperature, and respiratory rate, are used for the thermal comfort evaluation of sows (QUINIOU \& NOBLET, 1999; ANDERSEN et al., 2008). Furthermore, it is important to monitor environmental physical variables in order to characterize the different productive systems. RODRIGUES et al. (2011) defined the air specific enthalpy as an environmental index that jointly considers values of temperature, air relative humidity and local atmospheric pressure.

Other factors, such as the building floor type and its surface temperature, also influence processes of heat exchange between the animal and environment. Processes of thermal conductance, especially those derived from the contact between animals and the pen floor, compose the total thermal balance of the animal in its environment; however, these processes depend on other aspects as thermal resistance and heat capacity of the contact surfaces (DESHAZER et al., 2009).

The objective of this study was to verify the effect of two floor types, wood shavings and concrete, on the thermal comfort of gestating sows reared either in groups or under a combined system of crates and group pens.

\section{MATERIAL AND METHODS}

The study was performed at a commercial swine farm located in Itu County, São Paulo State, Brazil. The work comprised the monitoring of one sow pregnancy cycle from January to May 2010. A total of 216 animals were used, which were distributed in four treatments of 54 sows divided into three replications. Each replication had 18 grouped-pen sows. The treatments were implemented for the following evaluations:

- Combined pregnancy cycle: crates for the first 28 days after insemination and group pens for the pregnancy remainder $(\mathrm{CP}) \mathrm{x}$ entire pregnancy cycle in group pens $(\mathrm{P})$;

- Bedding use in the group system (BG) x compact concrete floor in the group system (FG).

Thus, the implemented treatments were CPFG, CPBG, PFG and PBG.

The used buildings were $3 \mathrm{~m}$ high and the experimental pens allowed the stocking rate of 2.5 $\mathrm{m}^{2}$ /sow. In the CPBG and PBG treatments, animals were housed on a $0.25 \mathrm{~m}$ layer of wood shavings; on the other hand, in the CPFG and PFG, animals were housed on a compact concrete floor. 
All evaluations were carried out in periods of three consecutive days distributed along the pregnancy cycle (eight evaluation periods for PFG and PBG treatments, and four for CPFG and $\mathrm{CPBG}$ ). Periods composed of three consecutive days of analyses were interleaved by nine days. Evaluations were performed three times per day (7:30 am, 12 noon, and 4:30 pm).

The adopted environmental variables were the dry-bulb temperature $\left({ }^{\circ} \mathrm{C}\right)$ and air relative humidity $(\%)$, which were registered by $\mathrm{HOBO} \AA$ data loggers settled at a central location of the experimental pens, at $1.5 \mathrm{~m}$ height.

Subsequently, values of air specific enthalpy (kJ.kg dry air ${ }^{-1}$ ) were calculated according to the eq. (1) described by RODRIGUES et al. (2011).

$$
h=1.006 * t+\frac{R H}{b p} * 10^{(7.5 t / 237.3+t)} *(71.28+0.052 t)
$$

Where,

$\mathrm{h}=$ Air specific enthalpy $\left(\mathrm{kJ} . \mathrm{kg}\right.$ dry $\left.\mathrm{air}^{-1}\right)$;

$\mathrm{t}=$ Dry-bulb temperature $\left({ }^{\circ} \mathrm{C}\right)$;

$\mathrm{RH}=$ Air relative humidity $(\%)$,

$\mathrm{bp}=$ Local barometric pressure (considering the value of $758 \mathrm{mmHg}$ ).

The surface temperature $\left({ }^{\circ} \mathrm{C}\right)$ of the pen floor was registered at two locations predefined as clean and dirty areas, by a thermographic camera of the FLUKE® brand, model TI25, which registered images from a distance of $1 \mathrm{~m}$, keeping an angle of $90^{\circ}$ from the concerned surface. Subsequently, the images were analyzed with the help of the software SMARTVIEW@, selecting the central area of each image. Values of mean temperature were then calculated for each image, adopting emissivity values of 0.75 and 0.95 for wood shavings and concrete surfaces, respectively (OMEGA ENGINEERING INC, 2007).

A theoretical model presented by FIALHO et al. (2004) was used to calculate the estimate of heat loss rate to the floor in both wood shavings and concrete floor systems (Eq. 2).

$$
q_{p}=\frac{(C t * C f)}{(C t+C f)} *(T b-T f)
$$

Where,

$\mathrm{q}_{\mathrm{p}}$ : Conductive heat loss rate to the floor $\left(\mathrm{W} \cdot \mathrm{m}^{-2}\right)$;

$\mathrm{Ct}$ : Coefficient of heat transfer from peripheral tissues $\left(\mathrm{W} \cdot \mathrm{m}^{-2} \cdot{ }^{\circ} \mathrm{C}\right)$;

Cf: Floor thermal conductance $\left(\mathrm{W} \cdot \mathrm{m}^{-2}{ }^{\circ} \mathrm{C}\right)$;

$\mathrm{Tb}$ : Body temperature $\left({ }^{\circ} \mathrm{C}\right)$,

Tf: Floor temperature $\left({ }^{\circ} \mathrm{C}\right)$.

The Ct estimated value was obtained by Eq. (3) presented by BRUCE \& CLARK (1979) when considering heat-stressed animals.

$$
C t=200 * \frac{W^{0} g^{0.33}}{m^{2}{ }^{\circ} \mathrm{C}} * W_{b}^{-0.33}
$$

Where,

$\mathrm{W}_{\mathrm{b}}$ : Body weight, estimated in $170 \mathrm{~kg}$.

Eq. (4) was used for the calculation of floor thermal conductance $(\mathrm{Cf})$ values, considering $\mathrm{Cf}_{0}$ (thermal conductance factors) values of 10.16 and $1.78 \mathrm{~W} \mathrm{~kg}^{1 / 3} \mathrm{~m}^{-2}{ }^{\circ} \mathrm{C}^{-1}$ for concrete and straw bedding (which was extrapolated to wood shavings), respectively (FIALHO et al., 2004).

$$
C f=\frac{C f_{0}}{W_{b}^{1 / 3} * k f * N^{1 / 2}}
$$


Where,

kf: Area of skin-floor contact,

$\mathrm{N}$ : Number of grouped animals.

For Cf calculation, it was considered that, when an animal is lying on one side, $20 \%$ of its body is in contact with the floor (TURNPENNY et al., 2000), so the kf value considered in Eq. (4) was 0.2 . Furthermore, $\mathrm{N}=1$ was considered because animals do not present a crowding habit under heat stress conditions.

The considered physiological variables were: skin surface temperature, rectal temperature, and respiratory rate. Evaluations were performed from one animal per pen.

For evaluation of the skin surface temperature, thermographic images of the animals were used, enabling the analysis of their head surface. Images were made using the thermographic camera described before, adopting the emissivity value of 0.98 as recommended by the manufactures for biological tissues. Mean temperature values of the selected plots were calculated using the software SMARTVIEW ${ }^{\circledR}$.

The rectal temperature was measured via the insertion of a digital clinical thermometer up to 2 $\mathrm{cm}$ in the animal rectum until stabilization. The respiratory rate was assessed via direct count for 20 $\mathrm{s}$, extrapolating this time to $1 \mathrm{~min}$.

For the analysis of the bedding influence on the response variables, a general linear model was used according to Eq. (5) (RENCHER \& SCHAALJE, 2008):

$$
\mathbf{Y}=\mu+\mathbf{P} \boldsymbol{\pi}+\mathbf{X} \boldsymbol{\beta}+\boldsymbol{\varepsilon},
$$

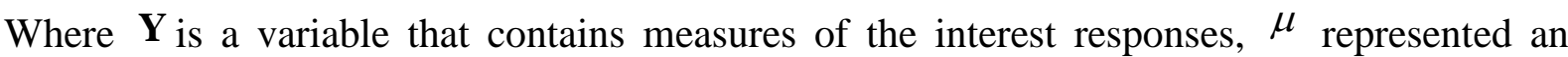
effect of the general mean for all observations, $\boldsymbol{\pi}$ is a vector of the variable effects that indicate the evaluation periods contained in the matrix $\mathbf{P}$, and $\boldsymbol{\beta}$ is the vector of the effects caused by the other studied factors. The vector $\boldsymbol{\varepsilon}$ was considered as having a normal distribution, with a vector of mean $\mathbf{0}$ and matrix of variances and covariances $\mathbf{I} \sigma^{2}$. The period factor was considered for all models regarding the response variables with the aim to reduce the effect of the different evaluation periods.

The MIXED procedure in the SAS® system was used to test the existence of correlations among pens and, also, sows. Such correlations were not identified; therefore, the GLM procedure was used for the adjustment of general linear models to the data.

\section{RESULTS AND DISCUSSION}

There was a difference $(\mathrm{p}<0.05)$ in the temperature and air specific enthalpy registered in the systems with or without bedding (Table 1). CORDEIRO et al. (2007) also found differences in the thermal characteristics of rearing environments when comparing a $0.5 \mathrm{~m}$ bedding of rice husk and wood shavings to a concrete floor in the initial period of the grow-finishing stage.

TABLE 1. Mean air temperature and enthalpy in the treatments with or without bedding

\begin{tabular}{lll}
\hline Treatment & Air temperature $\left({ }^{\circ} \mathrm{C}\right)$ & Specific enthalpy $\left(\mathrm{kJ} . k g\right.$ dry $\left.\mathrm{ar}^{-1}\right)$ \\
\hline With bedding & $25.97 \mathrm{a}$ & $55.25 \mathrm{a}$ \\
Without bedding & $24.83 \mathrm{~b}$ & $52.88 \mathrm{~b}$ \\
\hline
\end{tabular}

a,b Means followed by different letters differ from each other by the Tukey-Kramer test $(\mathrm{p}<0.05)$

Registered values of mean temperature were above the recommended range for gestating sows (from 7 to $23{ }^{\circ} \mathrm{C}$ ), regardless the treatment (NOBLET et al., 1989), what makes the experiment a period of great thermal challenge for the animals. 
The bedding effect was verified on the floor temperature at the dirty area with a mean increase of $2.61{ }^{\circ} \mathrm{C}$. Bedding presence at the rearing pens implies in the existence of a dry material that is able to progressively absorb feces and urine along the productive cycle. On the concrete floor, the dirty area was moist, what may explain the lower temperature values of this surface.

The results from the floor mean temperature at the dirty area are important for the thermal comfort evaluation in systems of swine rearing. Under heat conditions, the floor may be an important way of heat dissipation regarding its material of composition and existent moisture on its surface. In this sense, the wallowing habit of swines is an important behavioral pattern for their thermoregulatory processes (BRACKE, 2011).

At the clean area, on the contrary, there was an interaction between bedding presence and observation time. Differences among treatments were only observed in the afternoons, with higher values obtained from the treatments without bedding.

The material characteristics (concrete or wood shavings) associated with the floor surface temperature, at both clean and dirty areas, influenced the heat exchange dynamics between animal surface and floor. Table 2 presents values of $\mathrm{q}_{\mathrm{p}}$ (conductive heat loss rate to the floor, in W.m ${ }^{-2}$ ) as well as the main values used for its estimate.

TABLE 2. Conductive heat loss rate to the floor $\left(\mathrm{q}_{\mathrm{p}}\right)$ and variables used in its calculation for the concrete floor and bedding of wood shavings, at the clean and dirty areas

\begin{tabular}{lllll}
\hline Variable & \multicolumn{3}{c}{ Concrete } & Bedding \\
& Clean area & Dirty area & Clean area & Dirty area \\
\hline $\mathrm{Cf}^{1}\left(\mathrm{~W} \cdot \mathrm{m}^{-2} \cdot{ }^{\circ} \mathrm{C}^{-1}\right)$ & 9.33 & 9.33 & 1.63 & 1.63 \\
$\mathrm{Ct}^{2}\left(\mathrm{~W} \cdot \mathrm{m}^{-2} \cdot{ }^{\circ} \mathrm{C}^{-1}\right)$ & 36.73 & 36.73 & 36.73 & 36.73 \\
$\mathrm{~Tb}^{3}\left({ }^{\circ} \mathrm{C}\right)$ & 33.85 & 33.85 & 34.29 & 34.29 \\
$\mathrm{Tf}^{4}\left({ }^{\circ} \mathrm{C}\right)$ & 29.14 & 23.52 & 29.18 & 26.13 \\
$\mathrm{q}_{\mathrm{p}}\left(\mathrm{W} \cdot \mathrm{m}^{-2}\right)$ & 35.04 & 76.84 & 7.99 & 12.77 \\
\hline
\end{tabular}

${ }^{1}$ Floor thermal conductance; ${ }^{2}$ Coefficient of heat transfer from peripheral tissues; ${ }^{3}$ Body temperature estimated by the mean loin temperature obtained from the different treatments; ${ }^{4}$ Mean floor temperature of the different treatments at the clean and dirty areas.

For each of the different situations in which the animal exchanges heat through the skin (in contact with either the floor or air, in the shade or sunlight), the heat exchange dynamics depend on several factors: some are controlled by physiological mechanisms; others are directly related to the housing environment (FIALHO et al., 2004). The estimates of conductive heat loss to the concrete floor (Table 2) were 77.2 and $83.3 \%$ higher than to wood shavings, at the clean and dirty areas, respectively.

The floor type determines the conductive heat loss dynamics while the animal is lying down since different materials have diverse physical properties (DESHAZER et al., 2009). Values of $\mathrm{q}_{\mathrm{p}}$ calculated for both evaluated floor types, at the clean and dirty areas (Table 2), corroborate these statements and help to explain the pattern of physiological responses that indicate heat stress in both systems.

The mean rectal temperature (RT) obtained during the experiment was $38.28{ }^{\circ} \mathrm{C}$, with differences found only among the observation times $(\mathrm{p}<0.05)$. RT values were higher in the afternoons, followed by those observed at noon and in the mornings.

Under heat conditions, there might be a redirection of the blood flow from tissues to the skin, with a reduction of the internal temperature (BLACK et al, 1993) showed by RT. Therefore, RT, as a single variable, does not indicate the real animal thermoregulatory situation, so that it must be considered simultaneously with the skin temperature.

The mean skin temperature (ST) registered on the head area was higher in the bedding treatments (Table 3). The variation of ST values depends on external conditions and the animal 
need for heat loss, reflecting the variation of total body heat, although the core temperature may not have varied (DESHAZER et al., 2009). In fact, although the rectal temperature was not different among treatments with or without bedding, the head ST was distinct and responded to the greatest thermal challenge as well as the lowest heat loss rates to the floor in the bedding treatments.

TABLE 3. Mean skin temperature (head) in the treatments with and without bedding

\begin{tabular}{cc}
\hline Treatments & Mean skin temperature (head) $\left({ }^{\circ} \mathrm{C}\right)$ \\
\hline With bedding & $34.47 \mathrm{a}$ \\
Without bedding & $33.95 \mathrm{~b}$ \\
\hline
\end{tabular}

a,b Means followed by different letters differ from each other by the Tukey-Kramer test $(\mathrm{p}<0.05)$

The higher head ST in the bedding treatment is an indicator that animals in this system store more heat along the day because of their exposure to inappropriate conditions of heat exchange with the environment. Data presented by BLACK et al. (1993) showed that the upper critical temperature for lactating sows decreased from 25 to $22{ }^{\circ} \mathrm{C}$ for concrete and wooden floor, respectively. This information corroborates the results obtained in the present work, demonstrating that the floor material has a direct influence on the animal thermal comfort; this is so mainly due to the fact that this kind of animal remains lying on the floor most of the time (VAN DE WEERD \& DAY, 2009).

Animals from the bedding treatments presented higher respiratory rate (RR) in comparison with those maintained on the concrete floor, with an interaction observed between housing type and bedding presence (Table 4).

TABLE 4. Values of respiratory rate in the different treatments

\begin{tabular}{cc}
\hline Treatment & Respiratory rate $\left(\mathrm{mov}_{\mathrm{min}}{ }^{-1}\right)$ \\
\hline PBG & 72.68 \\
PFG & 65.11 \\
CPBG & 86.91 \\
CPFG & 66.56 \\
\hline
\end{tabular}

The normal RR, for gestating sows maintained under thermoneutral conditions (from 12 to 22 ${ }^{\circ} \mathrm{C}$ ), ranges between 26 and 27 mov. $\mathrm{min}^{-1}$ (QUINIOU \& NOBLET, 1999), which are lower values than those registered in this experiment, indicating the occurrence of unfavorable climatic conditions during the experimental period.

\section{CONCLUSIONS}

In general, thermodynamic aspects regarding the productive system are negatively affected by bedding systems, with physiological indicators evidencing heat stress.

\section{REFERENCES}

ANDERSEN, H.M.L.; JØRGENSEN, E.; DYBKJÆR, L.; JØRGENSEN, B. The ear skin temperature as an indicator of the thermal comfort of pigs. Applied Animal Behaviour Science, Amsterdam, v. 113, n.1, p. 43-56, 2008.

AVERÓS, X.; BROSSARD, L.; DOURMAD, L.J.Y.; GREEFC, K.H.; EDGE, H.L.;. EDWARDS, S.A.; MEUNIER-SALAUN, M.C. A meta-analysis of the combined effect of housing and environmental enrichment characteristics on the behaviour and performance of pigs. Applied Animal Behaviour Science, Amsterdam, v. 127, p.73-85, 2010.

BLACK, J.L.;MULLAN, B.P.;LORSCHY, M.L.;GILES, L.R. Lactation in the sow during heat stress. Livestock Production Science, Amsterdam, v. 35, n. 1, p. 153-170, 1993. 
BRACKE, M.B.M. Review of wallowing in pigs: Description of the behaviour and its motivational basis. Applied Animal Behaviour Science, Amsterdam, v. 132, n.1/2, p. 1-13, 2011.

BRUCE, J.M.; CLARK, J.J. Models of heat production and critical temperature for growing pigs. Animal Production, v. 28, p. 353-369, 1979.

CORDEIRO, M.B.; TINOCO, I.F.F.; OLIVEIRA, P.A.V.; MENEGALI, I.; GUIMARÃES, M.C.C.; BAETA, F.C.; SILVA, J.N. Efeito de sistemas de criação no conforto térmico ambiente e no desempenho produtivo de suínos na primavera. Revista Brasileira de Zootecnia, Viçosa, MG, v.36, n.5, p.1597-1602, 2007.

CORRÊA, E.K.; BIANCHI, I.; ULGUIM, R.R.; CORRÊA, M.N.; GIL-TURNES, C.; LUCIA JÚNIOR, T. Effects of different litter depths on environmental parameters and growth performance of growing finishing pigs. Ciência Rural, Santa Maria, v.39, n.3, 2009. Disponível em:

$<$ http://www.scielo.br/scielo.php?script=sci_arttext\&pid=S0103-

$84782009000300031 \& \operatorname{lng}=$ pt\&nrm=iso $>$. Acesso em: 5 nov. 2010.

DESHAZER, J.A.; HAHN, G.L. XIN, H. Basic principles of the thermal environment and livestock energetics. In: DESHAZER, J.A. (Ed). Livestock energetic and thermal environmental management. St. Joseph: ASABE, 2009. chap. 1, p. 1-22.

FIALHO, F. B.; BUCKLIN, R. A.; ZAZUETA, F. S.; MYER, R. O. Theoretical model of heat balance in pigs. Animal Science, Penicuik, v. 79, p. 121-134, 2004.

HOTZEL, M.J.; LOPES, E.J.C; OLIVEIRA, P.A.O.; GUIDONI, A.L. Behaviour and performance of pigs finished on deep bedding with wood shavings or rice husks in summer. Animal Welfare, Hertfordshire, v.18, p. 65-71, 2009.

NOBLET, J.; DOURMAD, J.Y.; LE DIVIDICH, J.; DUBOIS, S. Effect of Ambient Temperature and Addition of Straw or Alfalfa in the Diet on Energy Metabolism in Pregnant Sows. Livestock Production Science, Amsterdam, v. 21, p. 309 - 324, 1989.

OMEGA ENGINEERING. 2007. Disponível em: <http://www.omega.com/literature/transactions/ volume1/emissivityb.html>. Acesso em: 11 fev. 2010.

QUINIOU, N.; NOBLET, J. Influence of high ambient temperatures on performance of multiparous lactating sows. Journal of Animal Sscience, Champaign, v.77, n. 8, p.2124-2134, 1999.

RENCHER, A.C.; SCHAALJE, G.B. Linear Models in Statistics. New York: Wiley-Interscience, 2008. 663p.

RODRIGUES, V.C.; SILVA, I.J.O.; VIEIRA, F.M.C.; NASCIMENTO, S.T. A correct enthalpy relationship as thermal comfort índex for livestock. International Journal of Biometeorology, Lisse, v. 55, n.3, p.455-459, 2011.

SAS Institute. SAS/STAT 9.2 User's Guide. 2nded. Cary: SAS Institute, 2009.

SILVA, I.J.O.; PANDORFI, H.; PIEDADE, S.M.S. Influência do sistema de alojamento no comportamento e bem-estar de matrizes suínas em gestação. Revista Brasileira de Zootecnia, Viçosa, MG, v.37, n.7, p.1319-1329, 2008.

TURNPENNY, J.R.; WATHES, C.M.; CLARK, J.A.;MCARTHUR, A.J. Thermal balance of livestock 2. Applications of a parsimonious model. Agricultural and Forest Meteorology, Amsterdam, v. 101, n.1, p.29-52, 2000.

VAN DE WEERD, H.A.; DAY, J.E.L. A review of environmental enrichment for pigs housed in intensive housing systems. Applied Animal Behaviour Science, Amsterdam, v. 116, p. 1-20, 2009. 